UDK $577.1: 61$

ISSN 1452-8258

J Med Biochem 39: 1-6, 2020

\title{
VITAMIN D AND THIOL-DISULFIDE HOMEOSTASIS LEVELS IN POST- MENOPAUSAL WOMEN WITH OVERACTIVE BLADDER SYNDROME
}

\section{VITAMIN D I NIVOI TIOL-DISULFIDNE HOMEOSTAZE KOD ŽENA U POSTMENOPAUZI SA SINDROMOM PREAKTIVNE BEŠIKE}

\author{
Yasemin Ustundag ${ }^{1}$, Iknur Aykurt Karlıbel ${ }^{2}$, Murat Sambel ${ }^{3}$, Murat Ozturk $^{3}$, \\ Atilla Satır $^{3}$, Elif Yolgosteren ${ }^{2}$, Salim Neselioglu ${ }^{4}$, Ozcan Erel ${ }^{4}$ \\ ${ }^{1}$ Saglik Bilimleri University, Bursa Yuksek Ihtisas Education and Research Hospital, \\ Department of Clinical Laboratory, Bursa, Turkey \\ ${ }^{2}$ Saglik Bilimleri University, Bursa Yuksek Ihtisas Education and Research Hospital, \\ Department of Physical therapy and Rehabilitation, Bursa, Turkey \\ ${ }^{3}$ Saglik Bilimleri University, Bursa Yuksek Ihtisas Education and Research Hospital, \\ Department of Urology, Bursa, Turkey \\ ${ }^{4}$ Ankara Yildirim Beyazit University, Clinical Biochemistry, Ankara, Turkey
}

\section{Summary}

Background: This study aimed to find a relationship between vitamin $D$ concentration and thiol-disulfide homeostasis in the pathophysiology of overactive bladder (OAB) syndrome in postmenopausal women.

Methods: A total of 76 postmenopausal women, referred for routine controls, were recruited between January and March 2018 to participate in this study. Participants with an overactive bladder questionnaire $(O A B-q)$ score of $>11$ ( $=34$ ) were included in the $O A B$ syndrome group, while those with a score of $<5(n=42)$ were included in the control group. Serum total antioxidant capacity, ischemiamodified albumin, C-reactive protein, 25-hydroxy vitamin $D$ levels, and thiol-disulfide homeostasis were measured. Results: Patients with $O A B$ syndrome had waist circumferences of $106 \pm 11 \mathrm{~cm}$, and their body mass indexes (BMls) were $30.8 \pm 4.8 \mathrm{~kg} / \mathrm{m}^{2}$. The control groups' waist circumferences were $102 \pm 11 \mathrm{~cm}$ and their BMls were $28.9 \pm 4.3 \mathrm{~kg} / \mathrm{m}^{2}(p=0.069$ and $p=0.098$, respectively). The level of vitamin $D$ in the control group was 33.7 (IQR: 30.7$) \mathrm{nmol} / \mathrm{L}$ and 27.0 (IQR: 27.5) $\mathrm{nmol} / \mathrm{L}(\mathrm{p}=$ $0.081)$ in the $\mathrm{OAB}$ syndrome group.

\section{Kratak sadržaj}

Uvod: Cilj ove studije je bio da se nađe veza između koncentracije vitamina $D$ i tiol-disulfidne homeostaze u patofiziologiji sindroma preaktivne bešike $(O A B)$ kod žena u postmenopauzi.

Metode: Između januara i marta 2018. godine ukupno je odabrano 76 žena u postmenopauzi da bi učestvovale u ovoj studiji, koje su potom upućene na rutinske kontrole. Učesnice studije koje su imale skor od > $11(n=34)$ na upitniku za preaktivnu bešiku su uključene u grupu sa $O A B$ sindromom, dok su one sa skorom od $<5(n=42)$ uključene u kontrolnu grupu. Izmereni su ukupni antioksidativni kapacitet seruma, albumin modifikovan ishemijom, C-reaktivni protein, 25-hidroksi nivoi vitamina D i tiol-disulfidna homeostaza.

Rezultati: Pacijentkinje sa $O A B$ sindromom su imale obim struka od $106 \pm 11 \mathrm{~cm}$, a njihovi indeksi telesne mase (BMI) bili su $30,8 \pm 4,8 \mathrm{~kg} / \mathrm{m}^{2}$. Obim struka kontrolne grupe bio je $102 \pm 11 \mathrm{~cm}$, a njihovi BMI bili su 28,9 $\pm 4,3$ $\mathrm{kg} / \mathrm{m}^{2}$ ( $\mathrm{p}=0,069$ i $\mathrm{p}=0,098$, respektivno). Nivo vitamina D u kontrolnoj grupi bio je 33,7 (IQR: 30,7$) \mathrm{nmol} / \mathrm{L}$, u grupi sa OAB sindromom 27,0 (IQR: 27,5$) \mathrm{nmol} / \mathrm{L}(\mathrm{p}=$ 0,081).

Address for correspondence:

Yasemin Ustundag

Mimar Sinan Mah. Emniyet Cad. Polis Okulu Kar Isı Yıldırım,

Bursa, Turkey

Telephone: +905324823692

e-mail: yaseminbudak2000@yahoo.com 
Conclusions: We were not able to demonstrate with certainty any significant relationships between serum 25-hydroxy vitamin $D$ levels and thiol-disulfide homeostasis parameters and $\mathrm{OAB}$ syndrome.

Keywords: C-reactive protein, disulfides, postmenopause, urinary bladder, overactive, vitamin $\mathrm{D}$

\section{Introduction}

Overactive bladder $(O A B)$ syndrome is a common clinical condition that affects millions of people worldwide. It is defined by urgency, urinary incontinence, and frequency ( $>8 / 24$ hour) in the absence of metabolic (e.g. diabetes) or local pathological factors (1). Advanced age ( $>40$ years), menopause, parity $>2$, constipation, and high body mass index (BMI) are risk factors for OAB syndrome (1). Detrusor overactivity and involuntary contractions during the filling phase of the bladder result in decreased functional bladder capacity and associated symptoms (1).

Vitamin D, a fat-soluble prohormone, is biologically inert when derived from diet or elicited in the skin from sunlight, and requires two consecutive hydroxylations in the human body for activation. Vitamin $D$ plays an important role in the human body and its deficiency, related to many health problems, is a global issue (2).

Vitamin $D$ receptors are found in nearly 30 different tissues, including the human bladder (3). The pelvic floor musculature, which provides a constrictor mechanism for the urethra, expresses a vitamin $D$ receptor that plays a significant role in attaining urinary continence (4). It has been suggested that vitamin $D$ deficiency might lead to bladder dysfunction through its effect on the smooth muscles of the detrusor and pelvic musculature (3-5). Higher dietary vitamin $D$ intake has also been shown to lower the risk of OAB syndrome onset (6).

The loss of balance between reactive oxygen species (ROS) and antioxidant defence mechanisms against them is defined as oxidative stress. Vitamin D has been shown to have in vitro anti-oxidant and antiinflammatory effects, which might link vitamin $D$ deficiency to an increased probability of developing diseases $(7,8)$. In a recent study, Dokumacioglu et al. (9) showed that the levels of the oxidative stress markers, urinary malondialdehyde and 8-hydroxy-2'deoxyguanosine, increased in women with $O A B$ syndrome compared with a healthy control group.

Oxidative stress has been shown to contribute to the etiopathogenesis of some diseases, and it can be measured by a new marker, dynamic thiol-disulfide homeostasis $(10,11)$. This technique is simple and fast, and it can be used in routine laboratory practice to assess and monitor oxidative stress. Alvarez et al. (8) demonstrated that serum $25(\mathrm{OH}) \mathrm{D}$ concentra-
Zaključak: Nismo bili u mogućnosti da sa sigurnošću dokažemo bilo kakve značajne veze između nivoa 25-hidroksi vitamina $D$ u serumu i parametara tiol-disulfidne homeostaze i OAB sindroma.

Ključne reči: C-reaktivni protein, disulfidi, postmenopauza, mokra na be ika, preaktivna, vitamin $D$

tions were independently associated with major plasma thiol/disulfide redox systems, suggesting that vitamin $D$ status may be involved in redox-mediated pathophysiology.

In this study, we aimed to determine the relationship between vitamin D concentration and thioldisulfide homeostasis, as an oxidative stress marker, in the pathophysiology of $O A B$ syndrome in postmenopausal women.

\section{Materials and Methods}

The study was conducted in accordance with the Declaration of Helsinki and approved by the research ethics committee. All the subjects gave their written, informed consent, and all the authors followed the ICMJE's requirements for privacy.

Postmenopausal women who had been referred for routine controls (aged 50 or older), recruited between January and March 2018, were invited to participate in the study, and an OAB examination was performed in the urology clinic.

Women with urinary tract infections, urinary stones, infections, or other urinary system pathologies; a history of malignancy; current active malignant neoplasm; cardiovascular disease; chronic neurological, hematologic, infectious, musculoskeletal, psychiatric, or endocrine disease; stress urinary incontinence; those who smoked; take antioxidant drugs or vitamins; or receiving treatment for $O A B$ syndrome were excluded from the study. The participants who were accepted into the study answered an overactive bladder questionnaire (OAB-q) (12). The OAB-q included eight questions about the severity of a patient's complaints that were answered using a 6point scale, ranging between no (0), very few (1), a little (2), quite a few (3), a lot (4), and too many (5). The total score ranged between 0 and 40 .

In our study, those with an OAB-q score of $>11$ were evaluated as having $O A B$ syndrome. Those with an $O A B-q$ score $<5$ were included in the control group.

The patients' height, weight, and waist circumference were recorded, and a BMI was calculated as the weight in kilograms divided by the square of the height in meters $\left(\mathrm{kg} / \mathrm{m}^{2}\right)$. Serum calcium, phosphorus, triglyceride, high-density lipoprotein (HDL), low- 
Table I Characteristics of the study population.

\begin{tabular}{|c|c|c|c|}
\hline Characteristics & Women without $\mathrm{OAB}$ & Women with $\mathrm{OAB}$ & $\mathrm{p}$ \\
\hline Number of subjects $(n)$ & 34 & 42 & \\
\hline Age (years) & $54.0 \pm 3.4$ & $54.6 \pm 4.5$ & 0.600 \\
\hline OAB-q & $1(2.0)$ & $18(12.0)$ & $<0.001$ \\
\hline Waist circumference $(\mathrm{cm})$ & $102 \pm 11$ & $106 \pm 11$ & 0.069 \\
\hline $\mathrm{BMI}\left(\mathrm{kg} / \mathrm{m}^{2}\right)$ & $28.9 \pm 4.3$ & $30.8 \pm 4.8$ & 0.098 \\
\hline Waist circumference/height & $0.64 \pm 0.07$ & $0.67 \pm 0.07$ & 0.098 \\
\hline Triglyceride $(\mathrm{mmol} / \mathrm{L})$ & $1.86 \pm 1.12$ & $1.84 \pm 1.08$ & 0.927 \\
\hline Total cholesterol $(\mathrm{mmol} / \mathrm{L})$ & $6.05 \pm 1.13$ & $5.58 \pm 1.08$ & 0.071 \\
\hline $\mathrm{HDL}(\mathrm{mmol} / \mathrm{L})$ & $1.42 \pm 0.38$ & $1.42 \pm 0.43$ & 0.835 \\
\hline $\mathrm{LDL}(\mathrm{mmol} / \mathrm{L})$ & $3.7 \pm 0.98$ & $3.36 \pm 1.00$ & 0.089 \\
\hline AIP & $0.046 \pm 0.26$ & $0.048 \pm 0.31$ & 0.982 \\
\hline CRP (nmol/L) & $29.5(0.9)$ & $29.5(0.9)$ & 0.994 \\
\hline $\mathrm{Ca}(\mathrm{mmol} / \mathrm{L})$ & $2.39(0.07)$ & $2.37(0.12)$ & 0.724 \\
\hline Hba1c (\%) & $5.9(0.7)$ & $5.8(0.5)$ & 0.363 \\
\hline Vit D (nmol/L) & $33.7(30.7)$ & $27.0(27.5)$ & 0.081 \\
\hline PTH (pmol/L) & $6.15(3.9)$ & $6.68(4.0)$ & 0.715 \\
\hline FRAP $(\mu \mathrm{mol} / \mathrm{L})$ & $1120 \pm 264$ & $1135 \pm 283$ & 0.842 \\
\hline $\operatorname{Alb}(\mathrm{g} / \mathrm{L})$ & $55 \pm 17$ & $46 \pm 10$ & 0.151 \\
\hline IMA (AU) & $0.569 \pm 0.219$ & $0.629 \pm 0.257$ & 0.335 \\
\hline Native thiol $(\mu \mathrm{mol} / \mathrm{L})$ & $356 \pm 73$ & $331 \pm 64$ & 0.156 \\
\hline Total thiol $(\mu \mathrm{mol} / \mathrm{L})$ & $394 \pm 70$ & $365 \pm 65$ & 0.095 \\
\hline Disulfide $(\mu \mathrm{mol} / \mathrm{L})$ & $19.0 \pm 6.2$ & $17.0 \pm 4.2$ & 0.118 \\
\hline Disulfide/native thiol & $5.1(1.8)$ & $5.3(2.8)$ & 0.710 \\
\hline Disulfide/total thiol & $4.8(1.4)$ & $4.8(2.2)$ & 0.720 \\
\hline Native thiol/total thiol & $90.2(2.9)$ & $90.2(4.5)$ & 0.725 \\
\hline
\end{tabular}

Data are expressed as mean \pm standard deviation when normally distributed, otherwise as median (interquartile range). OAB-q: overactive bladder questionnaire; BMI: body mass index; HDL: high density lipoprotein; LDL: low density lipoprotein; Ca: calcium; Vit D: vitamin D, AIP: atherogenic index of plasma; CRP: C reactive protein; OAB: overactive bladder; IMA: ischemia-modified albumin; FRAP: ferric reducing power of plasma, AU: absorbance unit. ${ }^{*} p<0.05$ was considered significant for statistical analyses. Mann-Whitney $\mathrm{U}$ or student t used for statistical analysis.

density lipoprotein, and total cholesterol were measured using commercially available assay kits with an auto-analyzer (Olympus AU 2700; Beckman Coulter, Germany). HbA1c levels were measured with a HbA1c analyzer (G8; Tosoh Corporation, Tokyo, Japan); parathormone (PTH) and 25-hydroxy vitamin $D$ levels were measured using an immunoassay system (Advia Centaur XP; Siemens Healthcare Diagnostics, USA), and $C$ reactive protein (CRP) was measured with a nephelometer (BN II System; Siemens Healthcare Diagnostics, USA). The atherogenic index of plasma (AIP) was calculated as log (triglyceride/HDL-c). Total antioxidant capacity was measured using the ferric reducing ability of plasma method (FRAP) (13). Reduced cobalt to albuminbinding capacity levels (IMA) were determined according to the method defined by Bar-Or et al. (14). Thiol-disulfide homeostasis was measured by the method developed by Erel (15).

\section{Statistics}

Statistical analyses were performed using the SPSS program, Version 15 (SPSS Inc., Chicago, IL, USA). The normality of the continuous variables was analyzed using the Kolmogorov-Smirnov test. The results were expressed as the mean \pm the standard deviation (SD) or the median (interquartile range). Normally distributed continuous variables were compared using the independent sample t-test, but the Mann-Whitney $U$ test was used if the distribution was skewed. The relationships among the variables were examined using Spearman's correlation coefficient.

\section{Results}

A total of 76 menopausal women were included in the study. The patients, diagnosed with OAB syn- 
drome in the urology clinic, were divided into two groups according to their OAB-q scores: those with a score of $<5(n=34)$ were included in the healthy control group, and those with a score of $>11$ ( $n=$ 42) were classified as $O A B$ syndrome. Fourteen patients with scores between 5 and 10 were not evaluated.

The age of the patients and the healthy participants were similar at the time of the examination $(p=$ 0.600 ). Patients with $O A B$ syndrome had waist circumferences of $106 \pm 11 \mathrm{~cm}$ and BMls of $30.8 \pm 4.8$ $\mathrm{kg} / \mathrm{m}^{2}$. The control group had waist circumferences of $102 \pm 11 \mathrm{~cm}$ and BMls of $28.9 \pm 4.3 \mathrm{~kg} / \mathrm{m}^{2}$ ( $p=$ 0.069 and $\mathrm{p}=0.098$, respectively) (Table $\mathrm{l}$ ).

The level of vitamin $D$ in the control group was 33.7 (IQR: 30.7) $\mathrm{nmol} / \mathrm{L}$ and 27.0 (IQR: 27.5) $\mathrm{nmol} / \mathrm{L}$ in the OAB syndrome group $(\mathrm{p}=0.081)$ (Table I). However, the correlation between OAB-q and vitamin D using Spearman's correlation was statistically insignificant $(r=-0.095, \mathrm{p}=0.418)$.

The AIP was $0.048 \pm 0.31$ in women with $\mathrm{OAB}$ syndrome and $0.046 \pm 0.28$ in the control group $(p$ $=0.982$ ).

We found native thiol $356 \pm 83 \mu \mathrm{mol} / \mathrm{L}$ vs 331 $\pm 64 \mu \mathrm{mol} / \mathrm{L}(\mathrm{p}=0.444)$, total thiol $394 \pm 70 \mu \mathrm{mol} / \mathrm{L}$ vs $365 \pm 67 \mu \mathrm{mol} / \mathrm{L}(\mathrm{p}=0.095)$, and disulfide 19.0 $\pm 6.2 \mu \mathrm{mol} / \mathrm{L}$ vs $17.0 \pm 4.2 \mu \mathrm{mol} / \mathrm{L}(p=0.118)$ in the control vs the $O A B$ syndrome patients, respectively (Table I).

Vitamin D levels showed a weak negative correlation with waist circumference $(r=-0.339, p=$ $0.004)$, waist circumference to height ratio ( $r=$ -0.362 , $p=0.002)$, and BMI $(r=-0.68, p=$ $0.021)$. AIP correlated with waist circumference $(r=$ $0.823, p<0.001)$, waist circumference to height ratio $(r=0.349, p=0.003), B M I(r=0.384, p=$ $0.001)$, and FRAP $(r=0.345, p=0.007)$.

CRP had a weak positive correlation with waist circumference $(r=0.399, p=0.001)$, waist circumference to height ratio $(r=0.420, p<0.001)$, and BMI $(r=0.369, p=0.01)$. There was no correlation between the OAB-q score and any of the examined parameters. The thiol-disulfide homeostasis parameters did not correlate with any parameters investigated in the patient group.

\section{Discussion}

We found that the postmenopausal patients with $O A B$ syndrome levels of vitamin $D$ were non-significantly low compared to the control group. Supporting our study, low 25-hydroxy vitamin D blood test levels have been suggested as contributing to pelvic floor muscle weakness, which is involved in urinary incontinence and $O A B$ syndrome (16). High-dose vitamin $D$ therapy has been proven to reduce the severity of urinary incontinence in postmenopausal women (17, 18 ), and in a survey of 5,816 women aged over 40 years, high dietary vitamin $D$ intake was found to reduce the risk of developing $O A B$ syndrome (19). However, some studies did not find an association between lower urinary tract symptoms and vitamin $D$ deficiency (20). Similarly, in a Korean-patient group, low serum vitamin $D$ was not significantly related to female urinary incontinence matched for risk factors such as menopause, number of pregnancies, hypertension, diabetes, and BMI (21).

The vitamin $D$ levels in our study negatively correlated with waist circumference and BMI. Several studies have demonstrated evidence of an association between low plasma concentrations of 25-hydroxy vitamin D and obesity (22). BMI and waist circumference were higher in the $O A B$ syndrome patients. This was consistent with a recent meta-analysis by Zhu et al. (23) that showed that an increase in BMI is a risk factor for $O A B$ syndrome. The exact mechanisms, explaining the link between obesity and $O A B$ syndrome, are not well-known. In the current study, the inflammatory marker CRP was positively correlated with waist circumference, waist circumference to height ratio and BMI. These findings are in agreement with previously published reports (24).

ROS are normal products of aerobic metabolism. However, excess production of ROS is a common feature of various pathophysiological bladder conditions, although its possible role in the physiopathology of bladder dysfunction has still not been clarified $(25,26)$.

Masuda et al. (27) suggested that oxidative stress might play a role in the development of bladder dysfunction by increasing detrusor muscle contractility and stimulating bladder afferent fibres. With ageing, there seems to be a decrease in antioxidant mechanisms, and ageing increases the sensitivity of detrusor contraction to oxidative damage (28). Some studies have demonstrated that ROS mediate detrusor muscle activity, which provides insight into possible mechanisms $(27,29,30)$.

We speculated that the interplay between vita$\min D$ and oxidative stress might affect the severity of $O A B$ syndrome. However, in our study, total antioxidant capacity, measured as FRAP, and thiol-disulfide homeostasis in the OAB syndrome group were similar to those of the control group, and no correlation was found between the severity of the syndrome. No previous study has investigated thiol-disulfide homeostasis in patients with $O A B$ syndrome.

There was no relationship between vitamin $D$ and CRP in our study. Accordingly, Jorde et al. (31) could not find a correlation between 25-hydroxy vitamin $D$ blood test levels and a number of cytokines and inflammation markers. Yiu et al. (32) also demonstrated that vitamin $D$ did not have a signifi- 
cant effect on the serum biomarkers of inflammation and oxidative stress. In addition, we could not find an association between FRAP and vitamin D or vitamin D and CRP. This might be explained by the in vivo studies that have demonstrated that active vitamin $D$ in very high concentrations has an immunoregulatory effect (33).

Alvarez et al. (8) showed that in a large cohort of ambulatory adults, the serum 25-hydroxy vitamin $D$ concentration is related to the plasma circulating major thiol-disulfide redox systems; namely plasma glutathione (GSH), cysteine (Cys), and their associated disulfides. However, we found no correlation between vitamin $D$ and thiol-disulfide homeostasis.

Our study involves certain limitation. For instance, the number of participants in both groups

\section{References}

1. Leron E, Weintraub AY, Mastrolia SA, Schwarzman P. Overactive bladder syndrome: Evaluation and management. Curr Urol 2018; 11: 117-25.

2. Guessous I. Role of Vitamin D deficiency in extraskeletal complications: predictor of health outcome or marker of health status? Biomed Res Int 2015; 2015: 563403.

3. Damiati S. A Pilot study to assess kidney functions and toxic dimethyl-arginines as risk biomarkers in women with low vitamin D levels. J Med Biochem 2019; 38: 145-52.

4. Badalian SS, Rosenbau PF. Vitamin D and pelvic floor disorders in women. Results from the National Health and Nutrition Examination Survey. Obstet Gynecol 2010; 115: 795-803.

5. Schröder A, Colli E, Maggi M, Andersson KE. Effects of a vitamin $D(3)$ analogue in a rat model of bladder outlet obstruction. BJU Int 2006; 98: 637-42.

6. Dallosso HM, McGrother CW, Matthews RJ, Donaldson MM; Leicestershire MRC Incontinence Study Group. Nutrient composition of the diet and the development of overactive bladder: a longitudinal study in women. Neurourol Urodyn 2004; 23: 204-10.

7. Berridge MJ. Vitamin D deficiency accelerates ageing and age-related diseases: a novel hypothesis. J Physiol 2017; 595: 6825-36.

8. Alvarez JA, Chowdhury R, Jones DP, Martin GS, Brigham $\mathrm{KL}$, Binongo JN, et al. Vitamin $\mathrm{D}$ status is independently associated with plasma glutathione and cysteine thiol/disulfide redox status in adults. Clin Endocrinol (Oxf) 2014; 81: 458-66.

9. Dokumacioglu E, Demiray O, Dokumacioglu A, Sahin A, Sen TM, Cankaya S. Measuring urinary 8-hydroxy-2'deoxyguanosine and malondialdehyde levels in women with overactive bladder. Investig Clin Urol 2018; 59: 252-6.

10. Üstünda Y, Demirci H, Balık R, Erel O, Özaydın F, Kücük $B$, et al. Thiol/disulfide homeostasis in pregnant women was low. Another drawback of the study is that this cross-sectional study was conducted in only one centre and, thus generalizability may be limited.

In conclusion, we were not able to demonstrate with certainty any significant relationships between serum 25-hydroxy vitamin D levels and thiol-disulfide homeostasis parameters and $\mathrm{OAB}$ syndrome.

Acknowledgements. This research did not receive any specific grant from funding agencies in the public, commercial, or non-profit sectors.

\section{Conflict of interest statement}

The authors stated that they have no conflicts of interest regarding the publication of this article.

with obstructive sleep apnea syndrome. J Matern Fetal Neonatal Med 2017; 27: 1-6.

11. Polat $M$, Ozcan $O$, Sahan L, Üstündag-Budak Y, Alisik $M$, Yilmaz $N$, et al. Changes in thiol-disulfide homeostasis of the body to surgical trauma in laparoscopic cholecystectomy patients. J Laparoendosc Adv Surg Tech A 2016; 26(12): 992-6.

12. Coyne K, Revicki D, Hunt, Corey R, Stewart W, Bentkover $\mathrm{J}$ et al. Psychometric validation of an overactive bladder symptom and health-related quality of life questionnaire: the OAB-q. Qual Life Res 2002; 11: 563.

13. Üstünda $Y$, Huysal K, Kahvecio lu S, Demirci H, Yavuz S, Sambel $M$, et al. Establishing reference values and evaluation of an in-house ferric reducing antioxidant power (FRAP) colorimetric assay in microplates. The Europ Research J 2016; 2.2.

14. Bar-Or D, Lau E, Winkler JV. A novel assay for cobaltalbumin binding and its potential as a marker for myocardial ischemia-a preliminary report. J Emerg Med 2000; 19: 311-5.

15. Erel O, Neselioglu S. A novel and automated assay for thiol/disulfide homeostasis. Clin Biochem 2014; 47(18): 326-32.

16. Sharma S, Aggarwal N. Vitamin D and pelvic floor disorders J Midlife Health 2017; 8(3): 101-2.

17. Oberg J, Verelst M, Jorde R, Cashman K, Grimnes G. High dose vitamin $D$ may improve lower urinary tract symptoms in postmenopausal women. J Steroid Biochem Mol Biol 2017; 173: 28-32.

18. Digesu G, Verdi E, Cardozo L, Olivieri L, Khullar V, Colli E. Phase Ilb, multicenter, double blind, randomized, placebo-controlled, parallel group study to determine effects of elocalcitol in women with overactive bladder and idiopatic detrusor overactivity. Urology 2012; 80: 48-54.

19. Dallosso HM, McGrother CW, Matthews RJ, Donaldson MM, Leicestershire MRCISG. Nutrient composition of the 
diet and the development of overactive bladder: a longitudinal study in women. Neurourol Urodyn 2004; 23: 204-10.

20. Aydogmus H, Demirdal US. Vitamin D deficiency and lower urinary tract symptoms in women. Eur J Obstet Gynecol Reprod Biol 2018; 228: 48-52.

21. Lee $H S$, Lee JH. Vitamin $D$ and urinary incontinence among Korean Women: a Propensity Score-matched Analysis from the 2008-2009 Korean National Health and Nutrition Examination Survey. J Korean Med Sci 2017; 32(4): 661-5.

22. de Azevedo FR, Caramelli B. Hypovitaminosis D and obesity - Coincidence or consequence? Eur Endocrinol 2013; 9(2): 128-31.

23. Zhu J, Hu X, Dong X, Li L. Associations between risk factors and overactive bladder: A Meta-analysis. Female Pelvic Med Reconstr Surg 2018 Mar 9.

24. Lagunova Z, Porojnicu AC, Lindberg F, Hexeberg $S$, Moan J. The dependency of vitamin D status on body mass index, gender, age and season. Anticancer Res 2009; 29: 3713-20.

25. Chien CT, Yu HJ, Lin TB, et al. Substance $P$ via NK1 receptor facilitates hyperactive bladder afferent signalling via action of ROS. Am J Physiol Renal Physiol 2003; 284: F840-F851.

26. Chien WC, Hayakawa S, Shimizu K, Chien CT, Lai MK. Catechins prevents substance P-induced hyperactive bladder in rats via the downregulation of ICAM and ROS. Neurosci Lett 2004; 367: 213-7.
27. Masuda H, Kihara K, Saito K, Matsuoka Y, Yoshida S, Chancellor $M B$, et al. Reactive oxygen species mediate detrusor overactivity via sensitization of afferent pathway in the bladder of anaesthetized rats. BJU International 2007; 101: 775-80.

28. Aikawa K, Leggett RE, Levin RM. Effect of age on hydrogen peroxide mediated contraction damage in the male rat bladder. J Urol 2003; 170: 2082-5.

29. Damiati S. Serum levels of asymmetric and symmetric dimethylarginine in women with vitamin D deficiency and history of pregnancy loss - a pilot study. J Med Biochem 2018: 37: 441-7.

30. Tarcan T, Siroky MB, Krane RJ, Azadzoi KM: Isoprostane 8-epi PGF2alpha, a product of oxidative stress, is synthesized in the bladder and causes detrusor smooth muscle contraction. Neurourol Urodyn 2000; 19: 43-51.

31. Jorde R, Sneve M, Torjesen PA, Figenschau Y, Gøransson LG, Omdal R. No effect of supplementation with cholecalciferol on cytokines and markers of inflammation in overweight and obese subjects. Cytokine 2010; 50: 175-80.

32. Yiu YF, Yiu KH, Siu CW, Chan YH, Li SW, Wong LY, et al. Randomized controlled trial of vitamin $D$ supplement on endothelial function in patients with type 2 diabetes. Atherosclerosis 2013; 227(1): 140-6.

33. van Etten E, Mathieu C. Immunoregulation by 1,25-dihydroxy vitamin D3: basic concepts. J Steroid Biochem Mol Biol 2005; 97: 93-101. 